\title{
The effects of combined essential oils along with fumarate on rumen fermentation and methane production in vitro*
}

\author{
B. Lin, Y. Lu, J.H. Wang, Q. Liang and J.X. Liu ${ }^{1}$ \\ Institute of Dairy Science, Ministry of Education, Key Laboratory of Molecular Animal Nutrition, \\ Zhejiang University \\ Hangzhou 310029, P.R. China
}

(Received 17 June 2011; revised version 20 January 2012; accepted 15 March 2012)

\begin{abstract}
Two trials were conducted to investigate the effect of a combination of essential oils (CEO) along with fumarate on in vitro rumen fermentation. In trial 1, the essential oil (EO) from thyme, oregano, cinnamon and lemon were mixed at five different ratios. The CEO were applied at levels of $0-500 \mathrm{mg} / \mathrm{l}$. Addition of CEO decreased gas, methane, total volatile fatty acid (VFA) production at $24 \mathrm{~h}$ incubation in a dose-dependent manner. Methane tended to decrease much more than total VFA and gas at the same EO level. The mixture of oils at an equal ratio at $500 \mathrm{mg} / 1$ that decreased methane much more than VFA was chosen as the optimal combination. In trial 2, the optimal combination was used with $0,5,10$ or $15 \mathrm{mmol} / 1$ of monosodium fumarate. Addition of fumarate further decreased methane production, with $10 \mathrm{mmol} / 1$ fumarate resulting in the largest reduction $(80.2 \%)$ and the smallest decrease in total VFA $(5.7 \%)$ and gas production $(16.7 \%)$. Quantification of several ruminal microbe populations by RT-PCR showed that the optimal combination sharply decreased ruminal protozoa; the populations of fungi and fibrolytic bacteria were also decreased. In summary, at an appropriate level, CEO can inhibit methane production. Inclusion of fumarate can further decrease it, which is attributed mainly to inhibition of protozoa and methanogens.
\end{abstract}

KEY WORD: essential oil, monosodium fumarate, in vitro, rumen fermentation, methane, microbial population

\footnotetext{
* Supported partly by the National Natural Science Foundation of China, No.30972105 and ChinaAustralia Special Fund for Science and Technology, Grant No. 2010DFA31040

${ }^{1}$ Corresponding author: e-mail: liujx@zju.edu.cn
} 


\section{INTRODUCTION}

Methane is an important greenhouse gas that contributes to global warming, with ruminant livestock accounting for about $28 \%$ of human activity related to global methane emission (IPCC, 2007). Many rumen methane inhibitors, such as ionophores and nitrite, are being explored as feed additives to inhibit rumen methane production, but most of them tend to be eliminated due to safety concerns over animal-derived food (Szumacher-Szumacher et al., 2010). Alternatives are, therefore, required. Natural essential oils (EO) extracted from plants have been observed to reduce methane production, inhibit feed protein degradation, and increase rumen protein by-pass to further digestive tract segments (Calsamiglia et al., 2007). Although there are some observations that EO can reduce organic matter digestibility through inhibition of microbes, the acetate-to-propionate ratio and ruminal ammonia can be reduced through specific inhibition of Gram-positive microbes by EO because these bacteria usually belong to ruminal acetate- and ammonia-producing species (Szumacher-Strabel et al., 2010).

It is reported that the anti-microbial activity of EO is related to the chemical structure of their main active components (Castillejos et al., 2006). Thus, selective trials would be needed to determine the optimal EO and addition level that can inhibit methanogens but have little negative effects on ruminal fibre digestion. In our previous studies, it was observed that a combination of four EO active components at different ratios had a varied potential of reducing ruminal methane production (Lin et al., 2011). It is still unclear, however, what the effect on rumen fermentation and methane production will be when the combined natural essential oils are added, though there are reports that combining essential oils (CEO) may enhance their ability to reduce rumen methane and ammonia production (Newbold et al., 2004; Spanghero et al., 2008).

When an EO is used to inhibit methane production, the hydrogen produced by fibre digestion will accumulate in rumen fluids. An alternative pathway allowing for the capture of reducing equivalents spared from methanogenesis is, therefore, needed. Fumarate is the mid-product of rumen acetogenesis, and reduction of fumarate to succinate can draw electrons away from ruminal methanogenesis; this is seen as a potential method of decreasing methane production in ruminants (Ungerfeld et al., 2007).

It is hypothesized that a blend of different types of EO would exert a varied effect on methane production, and that an optimal combination can be found. Addition of essential oils together with fumarate would exert synergic effects on inhibition of ruminal methane production and promote hydrogen flow into the pathway of volatile fatty acid (VFA) synthesis. The objectives of this study were, therefore, to screen for optimal doses of CEO to decrease methane production in vitro (trial 1), and to examine the possible synergic effect of the CEO with sodium 
fumarate on rumen fermentation (trial 2). The rumen microbial population was analysed in the rumen samples taken from trial 2 to elucidate the effect of addition of $\mathrm{CEO}$ with fumarate on rumen microbiota.

\section{MATERIAL AND METHODS}

\section{Experimental design}

Two trials were conducted in this study. In trial 1, oils extracted from thyme (Thymus vulgaris), oregano (Origanum vulgare), cinnamon (Cinnamomum verum), and lemon (Citrus limonum) were mixed at ratios of 1:2:3:4, 2:1:4:3, 3:4:1:2, 4:3:2:1 and 1:1:1:1 to make up five different combinations (CEO1, CEO2, CEO3, CEO4, CEO5), respectively. These oils were produced by Jiangxi Essential Oil Extraction Company (Jiangxi, China). From a preliminary GC/MS analysis, these oils contained their responding components $(\mathrm{g} / \mathrm{kg})$ as below: 809 eugenol in thyme oil, 837 carvacrol in oregano oil, 855 cinnamaldehyde in cinnamon oil, and 801 limonene in lemon oil. Based on their main active components, two of the above combinations were phenol-based (CEO1 and CEO2), two, aldehyde-based (CEO3 and CEO4), and one, balanced (CEO5). Each combination was applied at level of $0,50,200$ and $500 \mathrm{mg} / \mathrm{l}$, respectively. An in vitro gas test was conducted to screen for the optimal combination and dose decreasing rumen methane production.

In trial 2, fumarate was added along with the optimal EO combination determined in trial 1 to study their synergic effect on rumen fermentation in vitro. Monosodium fumarate (Yuancheng Chemical Co, LtD., Wuhan, China, purity > $99 \%$ ) was added at a level of 5, 10 and $15 \mathrm{mmol} / \mathrm{l}$, respectively. An in vitro gas test was conducted to determine rumen fermentation parameters and microbial population.

\section{In vitro fermentations}

The incubations were conducted in $180 \mathrm{ml}$ serum bottles. Four bottles (replicates) were incubated for each combination at each dose in both trial 1 and 2. Each bottle contained oven-dried substrate ( $375 \mathrm{mg}$ ground maize kernels and $375 \mathrm{mg}$ of ground Leymus chinensis hay, DM based) (Theodorou et al., 1994). All the oil combinations were emulsified with Tween $80(0.2 \%, v / v)$ before use. The concentration of Tween 80 in all of the bottles was adjusted to be the same as that in $500 \mathrm{mg} / 1 \mathrm{EOAC}$ added bottles $(0.002 \%$, v/v). It has been verified that Tween 80 at such a level does not have any effect on rumen fermentation (Cong et al., 2009). Control treatments were set up to contain substrate and similar amounts of Tween 80 but no EO or fumarate. Four bottles containing incubation medium 
without any substrate and additives were incubated as blanks to correct the total gas production resulting from the activity of the rumen fluid. Designated amounts of the CEOs and fumarate were added to the bottles with substrate. The bottles were then sealed with butyl rubber stoppers and aluminum caps and stored at $39^{\circ} \mathrm{C}$ overnight.

Three Hu sheep $(35 \pm 2 \mathrm{~kg})$, fitted with rumen fistula, were used as donors of rumen fluid. They were fed on $850 \mathrm{~g}$ of a maintenance diet daily including $450 \mathrm{~g}$ of Leymus chinensis (Trin.) Tzvel hay and $400 \mathrm{~g}$ of concentrate mixture composed by maize, soyabean cake and wheat bran. A premix containing $119 \mathrm{~g} \mathrm{MgSO}_{4} \cdot \mathrm{H}_{2} \mathrm{O}$, $2.5 \mathrm{~g} \mathrm{FeSO}_{4} \cdot 7 \mathrm{H}_{2} \mathrm{O}, 0.8 \mathrm{~g} \mathrm{CuSO}_{4} \cdot 5 \mathrm{H}_{2} \mathrm{O}, 3 \mathrm{~g} \mathrm{MnSO}_{4} \cdot \mathrm{H}_{2} \mathrm{O}, 5 \mathrm{~g} \mathrm{ZnSO}_{4} \cdot \mathrm{H}_{2} \mathrm{O}, 10 \mathrm{mg}$ $\mathrm{Na}_{2} \mathrm{SeO}_{3}, 40 \mathrm{mg} \mathrm{KI}, 30 \mathrm{mg} \mathrm{CoCl} \cdot 6 \mathrm{H}_{2} \mathrm{O}, 95.000 \mathrm{IU}$ vitamin $\mathrm{A}, 17.500 \mathrm{IU}$ vitamin $\mathrm{D}$, and $18.000 \mathrm{IU}$ vitamin $\mathrm{E}$ was also fed to the sheep. The diet contained $10.9 \%$ of CP, $42.6 \%$ of NDF, $26.4 \%$ of ADF, and $25.6 \%$ of starch. Sheep were fed twice daily at 08.30 and $17.00 \mathrm{~h}$, and had free access to water. Rumen contents were obtained before the morning feeding from the three sheep in equal proportions, transported to the laboratory and filtered through four layers of cheesecloth to obtain the rumen fluids.

Each bottle was injected with $10 \mathrm{ml}$ prepared rumen fluid through the stopper using a syringe, the bottles shaken to mix the contents completely, and placed in an incubator at $39^{\circ} \mathrm{C}$. The pressure was recorded at 12 and $24 \mathrm{~h}$ of incubation using a pressure transducer (Zhang et al., 2008) to calculate total gas production. Methane production was also determined at 12 and $24 \mathrm{~h}$. At the end of the incubation, the incubation fluid were sampled and stored at $-20^{\circ} \mathrm{C}$ for later analysis of endproducts.

In trial 2, additional incubation fluids were sampled and stored at $-80^{\circ} \mathrm{C}$ for analysis of the rumen microbial population by real-time PCR.

\section{Procedures for determination of rumen fermentation parameters}

The $\mathrm{pH}$ value of rumen fluids was determined using a $\mathrm{pH}$ meter (model PB$10 / \mathrm{C}$, Sartorius, Germany) at the end of $24 \mathrm{~h}$ incubation. Methane concentrations were analysed by gas chromatography (GC) equipped with a flame ionization detector (FID) (Shimadzu 2010, Shimadzu corp., Japan) (Hu et al., 2005). The column (HP-INNOWAX, 19091N-133) of the GC was $30 \mathrm{~m} \times 0.25 \mathrm{~mm} \times 0.25$ $\mu \mathrm{m}$ in size and the temperature was $80^{\circ} \mathrm{C}$. Ammonia nitrogen was measured colorimetrically (Broderick and Kang, 1980) using a 721 spectrophotometer (Shanghai, China). Concentrations of VFA were analysed by GC as described elsewhere (Hu et al., 2005). 
Analysis of rumen microbe population

The DNA from rumen fluid obtained in trial 2 was extracted by the bead beating method with a mini-bead beater (Biospec Products, Bartlesville, OK, USA), as described by Zhang et al. (2008). The PCR primers designed for total bacteria, fungi, protozoa, methanogens, Fibrobacter succinogenes and Ruminococcus flavefaciens are listed in Table 1 (Denman and McSweeney, 2006). Quantitative PCR was performed with a 7500 Real-Time PCR System (Applied Biosystems) using the SYBR Premix Ex Taq II Perfect Real Time (TaKaRa Bio Inc.). The PCR mixture consisted of $2 \mu \mathrm{l}$ template DNA, $0.2 \mathrm{mM}$ dNTP, $0.3 \mu \mathrm{M}$ Primer, $1.5 \mathrm{mM}$ $\mathrm{MgCl} 2$, and $1.25 \mathrm{U}$ Taq in a total volume of $20 \mu \mathrm{l}$. The cocktails were initially denatured at $95^{\circ} \mathrm{C}$ for $10 \mathrm{~s}$, then 40 cycles of $95^{\circ} \mathrm{C}$ for $5 \mathrm{~s}$ and $60^{\circ} \mathrm{C}$ for $34 \mathrm{~s}$. Melting curve analysis was performed after amplification to verify the specificity of real-time PCR. Threshold cycle values $(\mathrm{Ct})$ were recorded for each kind of microbe and the microbe population was expressed as a proportion relative to total rumen bacterial $16 \mathrm{~S}$ rDNA according to the equation:

$$
\text { Relative quantification }=2^{-(\mathrm{Ct} \text { target }-\mathrm{Ct} \text { total bacteria })}
$$

Table 1. Ruminal microbe primers for qPCR assay

\begin{tabular}{lclc}
\hline Target Species & $\begin{array}{c}\text { Forward / } \\
\text { reverse }\end{array}$ & \multicolumn{1}{c}{ Primer sequence } & $\begin{array}{c}\text { Amplicon } \\
\text { (base pairs) }\end{array}$ \\
\hline Total bacteria & $\mathrm{F}$ & CGGCAACGAGCGCAACCC & 130 \\
& $\mathrm{R}$ & CCATTGTAGCACGTGTGTAGCC & \\
Methanogens & $\mathrm{F}$ & TTCGGTGGATCDCARAGRGC & 140 \\
& $\mathrm{R}$ & GBARGTCGWAWCCGTAGAATCC & \\
Total fungi & $\mathrm{F}$ & GAGGAAGTAAAAGTCGTAACAAGGTTTC & 120 \\
& $\mathrm{R}$ & CAAATTCACAAAGGGTAGGATGATT & \\
Protozoa & $\mathrm{F}$ & GCTTTCGWTGGTAGTGTATT & 223 \\
& $\mathrm{R}$ & CTTGCCCTCYAATCGTWCT & 121 \\
F. succinogenes & $\mathrm{F}$ & GTTCGGAATTACTGGGCGTAAA & \\
& $\mathrm{R}$ & CGCCTGCCCCTGAACTATC & 132 \\
R. flavefaciens & $\mathrm{F}$ & CGAACGGAGATAATTTGAGTTACTTAGG & \\
& $\mathrm{R}$ & CGGTCTCTGTATGTTATGAGGTATTACC & \\
\hline
\end{tabular}

the primers were designed by Denman and McSweeney (2006)

\section{Data calculation and statistical analysis}

Hydrogen recovery $(\%)$ was estimated as $(4 \mathrm{M}+2 \mathrm{P}+2 \mathrm{~B}) /(2 \mathrm{~A}+\mathrm{P}+4 \mathrm{~B}) \times 100$, the ratio of hydrogen consumed via $\mathrm{CH} 4 / \mathrm{VFA}$ was estimated as $4 \mathrm{M} /(2 \mathrm{P}+2 \mathrm{~B})$, where acetate $(\mathrm{A})$, propionate $(\mathrm{P})$, butyrate $(\mathrm{B})$ and methane $(\mathrm{M})$ production was expressed in mmol (Demeyer, 1991). Reduction in methane production by 
additives was usually accompanied by VFA reduction. Reductions in methane and VFA production were expressed as the proportion of total production in controls and calculated using the following equation:

$$
1-\frac{\text { methane or VFA production in treated incubations }}{\text { methane or VFA production in incubation with no added control }}
$$

Thus, the relative methane reduction potential (RMRP) of a treatment versus control, which was calculated as a ratio of reduction in methane production, divided by reduction in VFA production, was used to screen for the optimal combination.

Data in trial 1 were analysed as a two-way factorial design using the PROC GLM procedure of SAS (2005), according to the following statistical model:

$$
Y i j=\mu+\alpha i+\beta j+(\alpha \times \beta) i j+\varepsilon i j
$$

where: Yij - dependent variable, $\alpha \mathrm{i}$ - effect of CEOs $(\mathrm{i}=1,5), \beta \mathrm{j}$ - effect of dose $(\mathrm{j}=1,4)$, and $\varepsilon \mathrm{ij}$ is the residual error.

The data in trial 2 were analysed as one-way analysis of variance using the PROC GLM procedure of SAS (2005), according to the following statistical model:

$$
Y i j=\mu+\alpha i+\varepsilon i
$$

where: Yi - dependent variable, $\alpha \mathrm{i}$ - effect of $500 \mathrm{mg} / \mathrm{l}$ CEO5 with fumarate $(i=1,5)$ and $\varepsilon i$ is the residual error.

\section{RESULTS}

\section{Effect of combination of essential oils (CEOs) on rumen fermentation characteristics}

The rumen $\mathrm{pH}$ value was not affected by doses and types of CEO $(\mathrm{P}>0.05$, Table 2). Total gas and methane production were decreased by CEO in a dose-dependent manner $(\mathrm{P}<0.01)$, and type of CEO had no influence on total gas production, but significantly influenced methane output $(\mathrm{P}<0.01)$. The magnitude of methane production decrease by the phenolic-based (CEO3 and CEO4) and balanced combination (CEO5) was larger than by the aldehyde-based combinations (CEO1 and CEO2) at levels of 200 and $500 \mathrm{mg} / 1$. Ammonia $\mathrm{N}$ was decreased by CEO, with significantly lower values $(\mathrm{P}<0.05)$ at 200 or $500 \mathrm{mg} / \mathrm{l}$ than in controls and $50 \mathrm{mg} / \mathrm{l}$ in all combinations. Total VFA was decreased in a CEO dose-dependent manner and significantly influenced by CEO type $(\mathrm{P}<0.01)$. Addition of aldehyde-based combinations resulted in a greater reduction of VFA than phenolic-based or balanced combinations at $500 \mathrm{mg} / \mathrm{l}$. In general, the degree of reduction of methane production tended to be greater than of total gas and VFA production at levels of 200 or $500 \mathrm{mg} / \mathrm{l}$. 
Table 2. Effects of combined essential oils on in vitro fermentation parameters and methane production at $24 \mathrm{~h}$ of incubation

\begin{tabular}{|c|c|c|c|c|c|c|c|c|c|c|}
\hline \multirow{2}{*}{ Parameters $^{1}$} & \multirow{2}{*}{$\begin{array}{c}\text { Level } \\
\mathrm{mg} / 1\end{array}$} & \multicolumn{5}{|c|}{ Combinations of essential oils ${ }^{1}$} & \multirow{2}{*}{ SEM } & \multicolumn{3}{|c|}{ Effect } \\
\hline & & CEO1 & $\mathrm{CEO} 2$ & CEO3 & CEO4 & CEO5 & & $\mathrm{CEO}$ & level & int. \\
\hline \multirow[t]{4}{*}{$\overline{\mathrm{pH}}$} & 0 & 6.77 & 6.71 & 6.77 & 6.71 & 6.72 & 0.426 & 0.512 & 0.426 & 0.312 \\
\hline & 50 & 6.79 & 6.71 & 6.77 & 6.73 & 6.77 & & & & \\
\hline & 200 & 6.82 & 6.81 & 6.83 & 6.85 & 6.87 & & & & \\
\hline & 500 & 6.80 & 6.83 & 6.79 & 6.83 & 6.87 & & & & \\
\hline \multirow{4}{*}{$\begin{array}{l}\text { Gas, } \\
\mathrm{ml}\end{array}$} & 0 & 93.3 & 92.8 & 93.3 & 92.8 & 93.0 & 3.46 & 0.612 & $<0.001$ & 0.214 \\
\hline & 50 & 81.1 & 79.9 & 80.7 & 82.6 & 80.7 & & & & \\
\hline & 200 & 73.0 & 72.1 & 75.5 & 76.2 & 76.8 & & & & \\
\hline & 500 & 60.0 & 58.8 & 61.8 & 62.6 & 62.3 & & & & \\
\hline \multirow{4}{*}{$\begin{array}{l}\text { Methane, } \\
\text { mmol }\end{array}$} & 0 & 0.96 & 0.97 & 0.95 & 0.97 & 0.98 & 0.015 & 0.007 & $<0.001$ & 0.631 \\
\hline & 50 & $0.83^{\mathrm{c}}$ & $0.85^{b c}$ & $0.90^{\mathrm{a}}$ & $0.93^{\mathrm{a}}$ & $0.87^{b}$ & & & & \\
\hline & 200 & $0.81^{\mathrm{a}}$ & $0.80^{\mathrm{a}}$ & $0.76^{\mathrm{b}}$ & $0.77^{\mathrm{b}}$ & $0.79^{\mathrm{ab}}$ & & & & \\
\hline & 500 & $0.41^{\mathrm{a}}$ & $0.42^{\mathrm{a}}$ & $0.37^{b}$ & $0.38^{\mathrm{b}}$ & $0.37^{\mathrm{b}}$ & & & & \\
\hline \multirow{4}{*}{$\begin{array}{l}\text { Ammonia-N, } \\
\mathrm{mg} / \mathrm{l}\end{array}$} & 0 & 1.45 & 1.43 & 1.45 & 1.43 & 1.44 & 0.053 & 0.621 & 0.004 & 0.108 \\
\hline & 50 & 1.29 & 1.29 & 1.31 & 1.28 & 1.26 & & & & \\
\hline & 200 & $1.24^{\mathrm{a}}$ & $1.24^{\mathrm{a}}$ & $1.21^{\mathrm{ab}}$ & $1.17^{\mathrm{ab}}$ & $1.11^{\mathrm{b}}$ & & & & \\
\hline & 500 & $1.35^{\mathrm{a}}$ & $1.27^{\mathrm{a}}$ & $1.22^{\mathrm{b}}$ & $1.16^{\mathrm{b}}$ & $1.06^{\mathrm{c}}$ & & & & \\
\hline \multirow{4}{*}{$\begin{array}{l}\text { TVFA, }^{2} \\
\text { mmol }\end{array}$} & 0 & 3.81 & 3.84 & 3.81 & 3.84 & 3.82 & 0.104 & 0.013 & $<0.001$ & 0.089 \\
\hline & 50 & $3.80^{\mathrm{a}}$ & $3.82^{\mathrm{a}}$ & $3.71^{\mathrm{ab}}$ & $3.73^{\mathrm{ab}}$ & $3.58^{\mathrm{b}}$ & & & & \\
\hline & 200 & 3.48 & 3.5 & 3.51 & 3.51 & 3.53 & & & & \\
\hline & 500 & $2.45^{\mathrm{b}}$ & $2.49^{\mathrm{b}}$ & $2.98^{\mathrm{a}}$ & $3.08^{\mathrm{a}}$ & $3.12^{\mathrm{a}}$ & & & & \\
\hline \multirow[t]{4}{*}{$\mathrm{A} / \mathrm{P}^{2}$} & 0 & 2.71 & 2.74 & 2.71 & 2.74 & 2.75 & 0.066 & 0.035 & 0.005 & 0.548 \\
\hline & 50 & $2.45^{\mathrm{ab}}$ & $2.41^{\mathrm{b}}$ & $2.57^{\mathrm{a}}$ & $2.55^{\mathrm{a}}$ & $2.53^{\mathrm{a}}$ & & & & \\
\hline & 200 & $2.01^{\mathrm{ab}}$ & $2.05^{\mathrm{a}}$ & $2.10^{\mathrm{a}}$ & $2.11^{\mathrm{a}}$ & $1.92^{\mathrm{b}}$ & & & & \\
\hline & 500 & $2.70^{\mathrm{b}}$ & $2.93^{\mathrm{a}}$ & $2.30^{\mathrm{c}}$ & $2.27^{\mathrm{c}}$ & $2.13^{\mathrm{c}}$ & & & & \\
\hline \multirow{4}{*}{$\begin{array}{l}\text { H recovery } \\
(\%)\end{array}$} & 0 & 87.4 & 87.9 & 87.5 & 87.9 & 87.8 & 1.81 & 0.326 & 0.031 & 0.561 \\
\hline & 50 & 92.2 & 91.1 & 88.5 & 88.8 & 89.3 & & & & \\
\hline & 200 & 87.0 & 88.6 & 86.0 & 86.3 & 85.2 & & & & \\
\hline & 500 & $84.1^{\mathrm{a}}$ & $81.8^{\mathrm{ab}}$ & $78.2^{b}$ & $78.8^{\mathrm{b}}$ & $76.7^{\mathrm{b}}$ & & & & \\
\hline \multirow{4}{*}{$\begin{array}{l}2 \mathrm{H} \text { consumed } \\
\text { via } \mathrm{CH} 4 / \text { via } \\
\text { VFA }\end{array}$} & 0 & 1.45 & 1.46 & 1.45 & 1.44 & 1.45 & 0.053 & $<0.001$ & $<0.001$ & 0.355 \\
\hline & 50 & $1.32^{\mathrm{b}}$ & $1.32^{\mathrm{b}}$ & $1.43^{\mathrm{a}}$ & $1.44^{\mathrm{a}}$ & $1.41^{\mathrm{ab}}$ & & & & \\
\hline & 200 & $1.26^{\mathrm{a}}$ & $1.22^{\mathrm{ab}}$ & $1.16^{\mathrm{b}}$ & $1.14^{\mathrm{b}}$ & $1.21^{\mathrm{ab}}$ & & & & \\
\hline & 500 & $0.98^{\mathrm{a}}$ & $0.94^{\mathrm{a}}$ & $0.78^{b}$ & $0.75^{b}$ & $0.42^{\mathrm{c}}$ & & & & \\
\hline
\end{tabular}

${ }^{1} \mathrm{CEO} 1, \mathrm{CEO} 2, \mathrm{CEO} 3, \mathrm{CEO} 4, \mathrm{CEO} 5$ = combined essential oils from thyme, origano, cinnamon and lemon at ratios of $1: 2: 3: 4,2: 1: 4: 3,3: 4: 1: 2,4: 3: 2: 1$ and $1: 1: 1: 1$, respectively

${ }^{2}$ TVFA - total volatile fat acids; $\mathrm{A} / \mathrm{P}$ - ratio of acetate to propionate

a, b, c, d, means within a row with different superscripts differ $(\mathrm{P}<0.05)$

The dose of $\mathrm{CEO}$ significantly influenced $\mathrm{H}$ recovery and ratio of $\mathrm{H}$ consumed via methane to $\mathrm{H}$ via VFA $(\mathrm{P}<0.01)$. At the level of $50 \mathrm{mg} / \mathrm{l}, \mathrm{H}$ recovery was higher in aldehyde-based combinations than in other groups. There was no significant difference in $\mathrm{H}$ recovery at the level of $200 \mathrm{mg} / \mathrm{l}$. $\mathrm{H}$ recovery with every CEO was lower at 50 and $200 \mathrm{mg} / \mathrm{l}$ than at $500 \mathrm{mg} / \mathrm{l}$. 
The ratio of $\mathrm{H}$ consumed via methane to $\mathrm{H}$ via VFA decreased as the CEO level increased, and the ratio was lower at $500 \mathrm{mg} / \mathrm{l}$ compared with other levels of addition, with the lowest ratio occurring at $500 \mathrm{mg} / \mathrm{l}$ of CEO5. Figure 1 shows the RMRP values for the five combinations added at 200 and $500 \mathrm{mg} / \mathrm{l}$. The phenolbased and balanced combinations (CEO3, 4 and 5) tended to have higher RMRPs than the aldehyde-based combinations (CEO1 and CEO2). The RMRPs of CEO1 and CEO2 at $200 \mathrm{mg} / \mathrm{l}$ were greater than that at $500 \mathrm{mg} / \mathrm{l}$, while the RMRPs of CEO3, 4 and 5 at $200 \mathrm{mg} / 1$ were smaller than at $500 \mathrm{mg} / \mathrm{l}$. The greatest RMRP was observed with CEO5 at $500 \mathrm{mg} / \mathrm{l}$. In terms of the greatest RMRP value and lowest ratio of $\mathrm{H}$ consumed via methane to $\mathrm{H}$ via VFA, CEO5 at $500 \mathrm{mg} / \mathrm{l}$ was selected as the optimal combination and level.

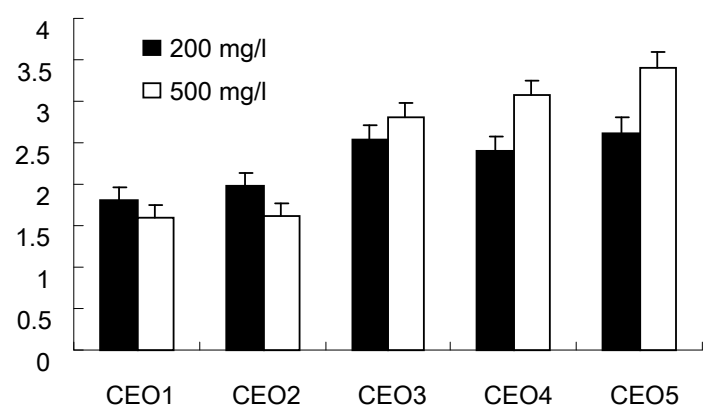

Figure 1. Relative methane reduction potential (RMRP) by different combinations of essential oils. RMRP - methane reduction relative to reduced total volatile fatty acids; CEO1, CEO2, CEO3, CEO4, CEO5 - combined essential oils from thyme, origano, cinnamon and lemon at ratios of 1:2:3:4, 2:1:4:3, 3:4:1:2, 4:3:2:1 and 1:1:1:1, respectively. The CEO5 at $500 \mathrm{mg} / 1$ had the highest RMRP among all the treatments

Effect of fumarate added along with CEO on rumen fermentation characteristics

No significant differences $(\mathrm{P}>0.05)$ were found in $\mathrm{pH}$ value among different treatments (Table 3). Total gas production significantly decreased in all CEO5 groups compared with the control $(\mathrm{P}<0.05)$, while fumarate had no influence on total gas production. Addition of fumarate significantly decreased methane production compared with CEO5 added alone, with $10 \mathrm{mmol} / \mathrm{l}$ being the most effective. Ammonia $\mathrm{N}$ was reduced by CEO5. Fumarate tended to increase total VFA compared with EO added alone, with the highest value at the level of 10 $\mathrm{mmol} / \mathrm{l}$ fumarate $(\mathrm{P}<0.05)$. Addition of $\mathrm{CEO}$ decreased the acetate proportion, while fumarate had no influence on it. The propionate proportion was increased in all CEO5 groups $(\mathrm{P}<0.05)$, with the largest increase in the fumarate-free group, followed by the $10 \mathrm{mmol} / \mathrm{l}$ fumarate group. The ratio of acetate to propionate 
Table 3. Effects of addition of $\mathrm{CEO}^{1}{ }^{1}(500 \mathrm{mg} / \mathrm{l})$ along with different doses of monosodium fumarate on in vitro rumen fermentation parameters at $24 \mathrm{~h}$ of incubation

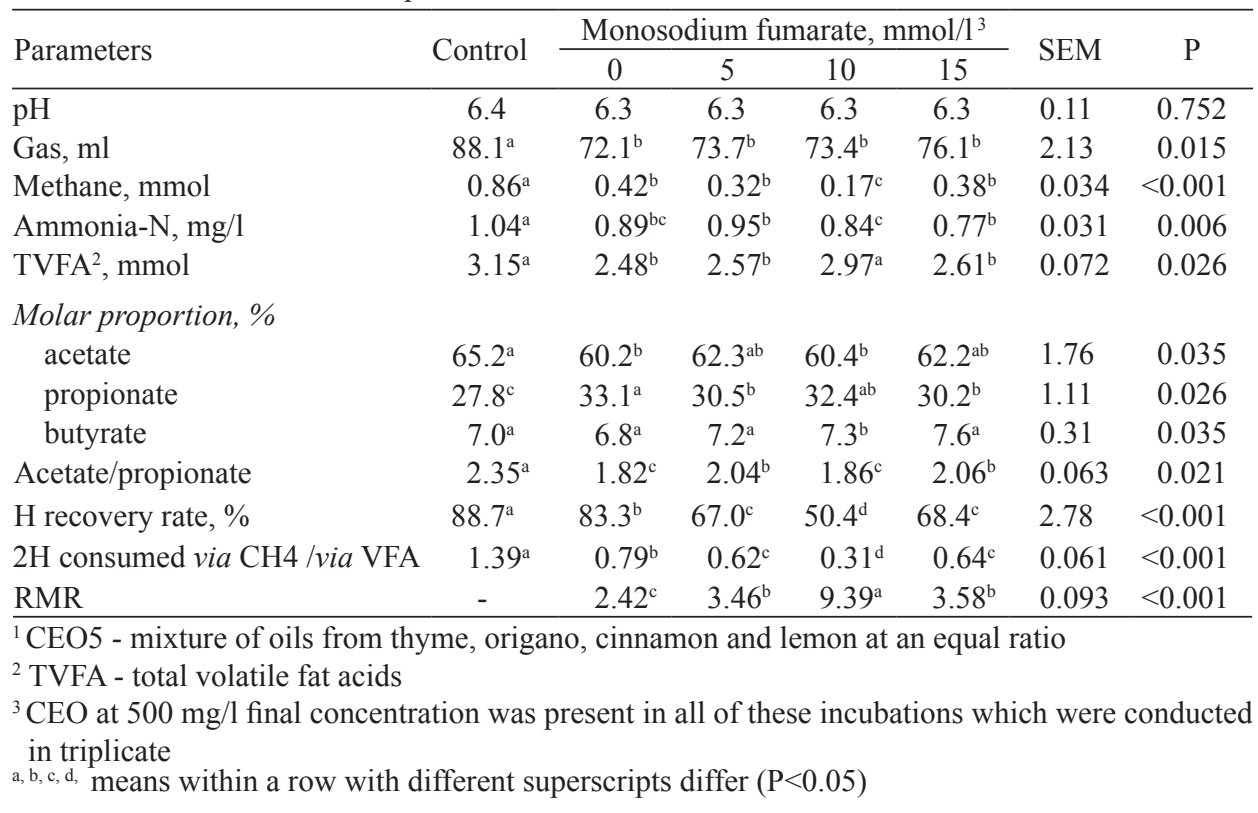

(A/P) was decreased in the CEO5 groups, whereas 5 and $15 \mathrm{mmol} / \mathrm{l}$ fumarate tend to increase $\mathrm{A} / \mathrm{P}$ compared with $\mathrm{CEO}$ added alone. $\mathrm{H}$ recovery and the ratio of $\mathrm{H}$ consumed via methane to $\mathrm{H}$ via VFA were decreased in CEO5 groups, and they were further decreased by addition of fumarate, and the lowest value of these two parameters was in the $10 \mathrm{mmol} / \mathrm{l}$ fumarate group. The RMRPs in fumarate groups were higher than in the fumarate-free group $(\mathrm{P}<0.05)$, with the highest RMRP found in the $10 \mathrm{mmol} / \mathrm{l}$ fumarate group.

\section{Effect of fumarate along with CEO on ruminal microbe population}

The population of rumen microbes relative to total bacterial $16 \mathrm{~S}$ rDNA is shown in Table 4. Methanogens were decreased by 40-50\% in CEO5 groups, but the dose of fumarate had no influence on this population. Protozoa were decreased by CEO5 compared with the control, and the extent of the decrease exceeded $93 \%$, i.e. much more than of the methanogen population. The fumarate dose had no influence on protozoa. Similar to protozoa, fungi were $50-90 \%$ decreased by CEO5, but fumarate $(5,10,15 \mathrm{mmol} / \mathrm{l})$ tended to increase the fungi population compared with EO added alone $(\mathrm{P}<0.05)$. Addition of $500 \mathrm{mg} / \mathrm{l} \mathrm{CEO5}$ decreased the number of two cellulolytic bacteria species, F. succinogenes and $R$. flavefaciens, and the dose of fumarate had no significant influence on their populations. 
Table 4. Effects of addition of $\mathrm{CEO}^{1}(500 \mathrm{mg} / \mathrm{l})$ along with different doses of monosodium fumarate on rumen microbial populations ( $\%$ of total bacterial $16 \mathrm{~S}$ rDNA)

\begin{tabular}{lccccccc}
\hline \multirow{2}{*}{ Microbes } & \multirow{2}{*}{ Control } & \multicolumn{7}{c}{ Monosodium fumarate, $\mathrm{mmol} / 1^{2}$} & \multirow{2}{*}{ SEM } & \multirow{2}{*}{$\mathrm{P}$} \\
\cline { 3 - 5 } & & 0 & 5 & 10 & 15 & & \\
\hline Methanogens $\left(\times 10^{-2}\right)$ & $52.3^{\mathrm{a}}$ & $32.2^{\mathrm{b}}$ & $27.1^{\mathrm{b}}$ & $30.6^{\mathrm{b}}$ & $27.2^{\mathrm{b}}$ & 2.54 & $<0.001$ \\
Protozoa & $2.68^{\mathrm{a}}$ & $0.14^{\mathrm{b}}$ & $0.13^{\mathrm{b}}$ & $0.15^{\mathrm{b}}$ & $0.15^{\mathrm{b}}$ & 0.060 & $<0.001$ \\
Fungi $\left(\times 10^{-2}\right)$ & $83.4^{\mathrm{a}}$ & $11.1^{\mathrm{d}}$ & $31.8^{\mathrm{c}}$ & $32.9^{\mathrm{c}}$ & $40.5^{\mathrm{b}}$ & 3.02 & $<0.001$ \\
F. succinogenes $\left(\times 10^{-2}\right)$ & $43.3^{\mathrm{a}}$ & $15.0^{\mathrm{b}}$ & $11.5^{\mathrm{b}}$ & $15.6^{\mathrm{b}}$ & $14.1^{\mathrm{b}}$ & 1.91 & $<0.001$ \\
R. flavefaciens $\left(\times 10^{-4}\right)$ & $58.4^{\mathrm{a}}$ & $28.4^{\mathrm{b}}$ & $22.8^{\mathrm{c}}$ & $28.8^{\mathrm{b}}$ & $27.3^{\mathrm{b}}$ & 2.14 & $<0.001$ \\
\hline
\end{tabular}

${ }^{1} \mathrm{CEO} 5$ - mixture of oils from thyme, origano, cinnamon, and lemon at an equal ratio

${ }^{2} \mathrm{CEO}$ at $500 \mathrm{mg} / \mathrm{l}$ final concentration was present in all of these incubations which were conducted in triplicate

a, b, c, d, means within a row with different superscripts differ $(\mathrm{P}<0.05)$

\section{DISCUSSION}

The biological properties of essential oils are mainly determined by their principal active components and vary with the chemical structure of the chief component (Castillejos et al., 2006; Spanghero et al., 2008). Therefore, a blend of different types of EO would be expected to exert a synergic effect on rumen fermentation (Spanghero et al., 2008). In the current study, the effects of five different EO combinations composed of phenolic-based oils (thyme oil and oregano oil) and aldehyde-based oils (cinnamon oil and lemon oil) on methane production were compared. Methane production was decreased much more than total VFA and total gas production was at the same level for all types of CEO (Table 2 ). The RMRP value was adopted to identify the optimal combination that could decrease methane production but have only a small influence on feed degradation. The RMRP with $500 \mathrm{mg} / 1$ of CEO1 or CEO2 was lower than with CEO3 and CEO4, but the highest RMRP was found with the balanced combination (CEO5). This difference may be attributed to the varying anti-microbial activities among aldehyde- and phenolic-based oils at this level (Macheboeuf et al., 2008). The mechanism of EO action was closely related to their lipophilic characteristics. Some of these oils can destroy the cell membrane of microbes, while some function through binding proteins and disturbing the metabolism of cells (Gill and Holley, 2004). The different mechanisms of action of these EOs against microbes may have contributed to the differing fermentation profiles obtained with different CEOs.

The $\mathrm{H}$ balance analysis shows that the ratio of $\mathrm{H}$ consumed via methane to $\mathrm{H}$ via VFA was lower in every EO group compared with groups without EO, indicating that addition of $\mathrm{EO}$ was more effective in driving $\mathrm{H}$ into the VFA synthesis pathway and not into methanogenesis. This result is consistent with 
the decrease in the $\mathrm{A} / \mathrm{P}$ ratio in $\mathrm{EO}$ groups. The lowest ratio of $\mathrm{H}$ consumed via methane to $\mathrm{H}$ via VFA was observed with CEO5 at $500 \mathrm{mg} / 1$, in which the highest RMRP was also obtained. CEO5 at $500 \mathrm{mg} / \mathrm{l}$ was selected, therefore, as the optimal combination and dose for further study with fumarate. The RMRP values and $\mathrm{H}$ consumed via VFA synthesis in the three fumarate groups were higher than in the EO only group, indicating that the methane reduction potential of EO was enhanced by addition of fumarate. When $10 \mathrm{mmol} / 1$ fumarate were added along with $500 \mathrm{mg} / \mathrm{l}$ of CEO5, methane production was further decreased by $59.5 \%$, while total VFA increased by $19.8 \%$ compared with EO added alone. Nevertheless, the effect of $15 \mathrm{mmol} / \mathrm{l}$ of fumarate on methanogenesis was not greater than that of $10 \mathrm{mmol} / \mathrm{l}$. Since fumarate is an intermediate product in rumen metabolism, addition of fumarate at a high level will induce its accumulation, which might inhibit nutrient fermentation and result in low production of total gas and VFA in the rumen. Addition of an appropriate level of fumarate with CEO is, therefore, recommended. Substantial reduction of methane by fumarate was observed in an in vivo study by Wood et al. (2004), who reported that the methane determined by addition of $100 \mathrm{~g} / \mathrm{d}$ fumarate could be decreased much more than the value calculated stoichiometrically.

Among all the parameters in trial 1 and 2, the $\mathrm{pH}$ value remained stable in all the treatments. The high buffering ability used in our in vitro system may prevent the $\mathrm{pH}$ from declining during fermentation. The decrease in ammonia $\mathrm{N}$ and increase in the proportion of propionate by addition of EO usually reported in other studies were also observed in our experiment. This may be due to inhibition of hyper-ammonia producing bacteria and acetate producers, which belong mainly to Gram-positive rumen bacteria and are sensitive to essential oils (McIntosh et al., 2003).

In the current study, CEO5 inhibited all of the measured rumen microbes, but protozoa, fungi, and two cellulolytic bacteria species were reduced to a higher extent than methanogens (Table 4). Inhibition of protozoa may be one of the main effects of essential oils on rumen fermentation (Calsamiglia et al., 2007; Hart et al., 2008), since reduced protozoa would decrease ecto- and endo-symbiotic methanogens with protozoa and lead to decreased methane production (Hu et al., 2005). The fungi-inhibiting effect by EO reported by other researchers (Soylu et al., 2007) was also obvious in this study. Rumen fungi can weaken feed particle structure and penetrate plant tissues. Thus, the reduction in fungi was not beneficial for rumen fibre digestion; this is also one reason for the reduction of VFA in the present study. The two cellulolytic bacteria, F. succinogenes and R. flavefaciens, were negatively affected by CEO5, suggesting that CEO5 would decrease fibre digestibility. Addition of fumarate along with CEO5 showed little effect on the population of rumen microbes, except fungi which were increased in the fumarate- 
added treatments. This may have resulted in the higher VFA production in the fumarate-added group than in the CEO5-only treatment.

Inhibition of protozoa can reduce deamination activity and result in decreased ruminal ammonia and feed protein degradation (Szumacher-Strabel et al., 2010). Although microbial protein, which usually accounts for more than $50 \%$ of the protein supply for animals, was not measured in our study, most studies that have evaluated the effects of $\mathrm{EO}$ on rumen microbial fermentation have not observed an influence on the synthesis of microbial protein (McIntosh et al., 2000; Wallace et al., 2002). On the other hand, a decrease in feed protein degradation by EO would increase the by-pass of protein and thus increase the total protein supply to animals. Further study is needed to confirm this.

\section{CONCLUSIONS}

Addition of combined essential oils (CEO) inhibited rumen fermentation and reduced the population of rumen microbes, while methane production, ruminal ammonia, and the ratio of acetate to propionate was also decreased by (CEO). The combination of esential oils (EO)s with different modes of action resulted in varying inhibitory effects on methane production, indicating that blending several types of EO is a potentially effective methane inhibitor. Addition of fumarate with CEO can further decrease methane production and alleviate the VFA-decreasing effect compared with an EO mixture alone. The coupled addition of fumarate with EO is, therefore, a better choice for inhibiting ruminal methane production.

\section{REFERENCES}

Broderick G.A., Kang J.H., 1980. Automated simultaneous determination of ammonia and total amino Aacids in ruminal fluid and in vitro media. J. Dairy Sci. 63, 64-75

Calsamiglia S., Busquet M., Cardozo P.W., Castillejos L., Ferret A., 2007. Invited Review: Essential Oils as Modifiers of Rumen Microbial Fermentation. J. Dairy Sci. 90, 2580-2595

Castillejos L., Calsamiglia S., Ferret A., 2006. Effect of essential oil active compounds on rumen microbial fermentation and nutrient flow in in vitro systems. J. Dairy Sci. 89, 2649-2658

Cong Z.H., Tang S.X., Tan Z.L., Sun Z.H., Zhou C.S., Han X.F., Wang M., Ren G.P., 2009. Effects of different nonionic surfactants on in vitro fermentation characteristics of cereal straws. J. Anim. Sci. 87, 1085-1096

Demeyer D.I. 1991. Quantitative aspects of microbial metabolism in the rumen and hindgut. In: J. P. Jouany (Editor). Rumen Microbial Metabolism and Ruminant Digestion. INRA Editions, Paris (France), pp. 217-237

Denman S.E., McSweeney C.S., 2006. Development of a real-time PCR assay for monitoring anaerobic fungal and cellulolytic bacterial populations within the rumen. FEMS Microbiol. Ecol. 58, 572-582 
Gill A.O., Holley R.A., 2004. Mechanisms of bactericidal action of cinnamaldehyde against Listeria monocytogenes and of eugenol against L. monocytogenes and Lactobacillus sakei. Appl. Environ. Microbiol. 70, 5750-5755

Hart K.J., Yáñez-Ruiz D.R., Duval S.M., McEwan N.R., Newbold C.J., 2008. Plant extracts to manipulate rumen fermentation. Anim. Feed Sci. Tech. 147, 8-35

Hu W.L., Liu J.X., Ye J.A., Wu Y.M., Guo Y.Q., 2005. Effect of tea saponin on rumen fermentation in vitro. Anim. Feed Sci. Tech. 120, 333-339

IPCC, Intergovernmental Panel on Climate Change, 2007. Climate Change. The Scientific Basis. Cambridge University Press, Cambridge (UK)

Lin B., Wang J.H., Lu Y., Liang Q., Liu J.X., 2011. In vitro rumen fermentation and methane production are influenced by active components of essential oils combined with fumarate. J. Anim. Physiol. Anim. Nutr. (in press). DOI: 10.1111/j.1439-0396.2011.01236.x

Macheboeuf D., Morgavi D.P., Papon Y., Mousset J.L., Arturo-Schaan M., 2008. Dose-response effects of essential oils on in vitro fermentation activity of the rumen microbial population. Anim. Feed Sci. Tech. 145, 335-350

McIntosh F.M., Newbold C.J., Losa R., Williams P., Wallace R.J., 2000. Effects of essential oils on rumen fermentation. Reprod. Nutr. Dev. 40, 221-222

McIntosh F.M., Williams P., Losa R., Wallace R.J., Beever D.A., Newbold C.J., 2003. Effects of essential oils on ruminal microorganisms and their protein metabolism. Appl. Environ. Microbiol. 69, 5011-5014

Newbold C.J., McIntosh F.M., Williams P., Losa R., Wallace R.J., 2004. Effects of a specific blend of essential oil compounds on rumen fermentation. Anim. Feed Sci. Tech. 114, 105-112

SAS, 2005. SAS Online Doc Version 9.1.3. SAS Institute, Inc. Carry, NC

Soylu S., Yigitbas H., Soylu E.M., Kurt E., 2007. Antifungal effects of essential oils from oregano and fennel on Sclerotinia sclerotiorum. J. Appl. Microbiol. 103, 1021-1030

Spanghero M., Zanfi C., Fabbro E., Scicutella N., Camellini C., 2008. Effects of a blend of essential oils on some end products of in vitro rumen fermentation. Anim. Feed Sci. Tech. 145, 364-374

Szumacher-Strabel M., Cieślak A., 2010. Potential of phytofactors to mitigate rumen ammonia and methane production. J. Anim. Feed Sci. 19, 319-337

Theodorou M.K., Williams B.A., Dhanoa M.S., McAllan A.B., France J., 1994. A simple gas production method using a pressure transducer to determine the fermentation kinetics of ruminant feed. Anim.Feed Sci. Tech. 48, 185-197

Ungerfeld E.M., Kohn R.A., Wallace R.J., Newbold C.J., 2007. A meta-analysis of fumarate effects on methane production in ruminal batch cultures. J. Anim Sci. 85, 2556-2563

Wallace R.J., McEwan N.R., McIntosh F.M., Teferedegne B., Newbold C.J., 2002. Natural products as manipulators of rumen fermentation. Asian-Austr. J. Anim. Sci. 10, 1458-1468

Wood T.A., Wallace R.J., Rowe A., Price J., Yáñez-Ruiz D.R., Murray P., Newbold C.J., 2009. Encapsulated fumaric acid as a feed ingredient to decrease ruminal methane emissions Anim. Feed Sci.Tech. 152, 62-71

Zhang C.M., Guo Y.Q., Yuan Z.P., Wu Y.M., Wang J.K., Liu J.X., Zhu W.Y., 2008. Effect of octadeca carbon fatty acids on microbial fermentation, methanogenesis and microbial flora in vitro. Anim. Feed Sci. Tech. 146, 259-269 